\title{
Lung Cancer pT2a TNM Finding v8
}

National Cancer Institute

\section{Source}

National Cancer Institute. Lung CancerpT2a TNM Finding v8. NCI Thesaurus. Code C136454.

Lung cancer with tumor measuring more than $3 \mathrm{~cm}$ but $4 \mathrm{~cm}$ or less in greatest dimension. (from AJCC 8th Ed.) 